\section{文献}

1）長野正満，結城康夫，後藤共子，井出隆一：“緎 学誌", 29, T-461(1973)

2）後藤共子，長野正满，結城康夫，小田隆，高井 博和：“緎学誌”，30, T-381(1974)

3)後藤共子，久和純一，結城虚夫，長野正满：“瀻 学誌”, 30,T-530(1974)

4) 後藤共子, 長野正满, 田中敬造: “瀻学誌”, 31, $\mathrm{T}-121(1975)$

5）後藤共子，舆野正满，結城康夫，小田隆，高井 博和：“瀻学誌”，31，T-104(1975)

6) 日本金属学会編：“金属便覧”，丸普林式会社， (1971) p. 1666

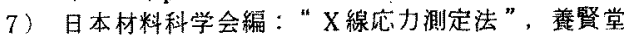
(1966)
8）林紘三郎：“材料”，21，486,612(1972)

9）有間漳一，細川智生，本田和男：“材料”，18, 1060(1969)

10) 平修三，林紘三郎：“材料”，19.647(1970)

11) 平 修二，林紘三郎：“材料”，18，1047(1969)

12）平挌二, 林紘三稘, 浦川琂夫：“"金属学会誌”, 35, $189(1971)$

13）平修二，吉岡靖夫：“日本機诚学会論文集”， 30, 1142(1964)

14) C. S. Barrett : "Structure of Metals", McGrow-Hill, (1952), 534

15）日本金属学会强度委員会編：“金属材料の強度と 破壊”，p.560，丸善(株)，(1964)

16) 岩本貢, 菊池初太郎, 半出莧, 鏡 嘉明; “材 料”, 16,962(1966)

\title{
電気湿度計を用いたダイナミック法による 布地の透湿性*
}

神奈川買工:柴試験所尾 崎 晶子

\author{
ESTIMATION OF FABRIC MOISTURE-PERMEABILITY \\ BY THE DYNAMIC METHOD OF NON-STATIONARY STATE
}

\author{
By Akiko Ozaki \\ (Industrial Research Institute of Kanagawa Prefecture, \\ Kanazawa-ku, Yokohama, Japan)
}

For the purpose of studying the factors involved in evaluating fabric comfort in wear, moisture permeation at non-stationary state in the closed vessel was measured by the dynamic method using an electric hygrometer, and the practical application to the measuring of fabric moisture-permeability was discussed in the light of the obtained results.

1) The diffusion layer of water vapour reaches up to $10 \mathrm{~mm}$. hight above the water surface at $20{ }^{\circ} \mathrm{C}$ in a closed system $(82 \mathrm{~mm} . \phi, 165 \mathrm{cc}$. volume). The diffusion layer is not disturbed even when a fabric was placed at the diffusion layer fringe.

2) Accordingly, an electric hygrometer was set up within the diffusion layer for satisfactory measurement of moisture-permeability.

3) The measurements on the polyester-ramie fabrics show that the observed decrease in the diffusion rate of water vapour due to the presence of a fabric is linearly related with moisture absorption rate, volume fraction of fiber and air-permeability of fabrics.

4) The dynamic method as applied in the present study turned out to be a rapid and convenient method for determining the fabric moisture-permeability and some important factors related to comfort in wear.

(Received January 27, 1975)

\footnotetext{
*この報交を「饰の着用快適性に関する研究(第 1 報)， Study of Estimating Fabric Comfort in Wear (Part I)」とする。
} 


\section{1. 緒}

布地の透湿性を測定する最も一般的な方法は，透湿力 ッブ法であり，多くの研究〉がなされている。こ扎は， 布も含めで定常的な采ての測定て，この方法からは，広 羲の透湿現象が観察される。広義の透湿は，緎維空隙を 伝わってくる水蒸気の透過と緎維自身を伝わってくる吸

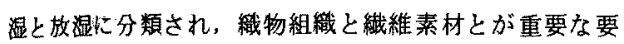

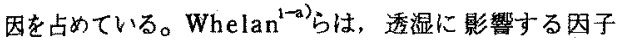
として，布の厚さと緎維体積率をあげている。Fourt ${ }^{1-わ)}$ らは、裁維をバラレルに樹脂中に埋めた場合の，紻維自 身の透湿性について検討し，吸湿性の高い維ほどみか けの措散係数が大をくなることを見い出している。これ らのことから，布地の透湿性には，吸湿性，厚さ，䋐維 体掅率の複合された効果が含まれることになるが，これ 方を同時測定する方法は未だ確立されていない。電気湿 度計を用いたダイナミック法代は，いわゆる非定常状態 ての測定であるので，着用快適性を評洒する上で重要 な因子となる透湿性と吸湿性を同時に測定できるはずて ある。タイイナック法は，2つの湿度勾配の間に試料を 買き，一方の部屋の湿度変化を電気湿度計でとらえるも のでり，斉藤りらは、フィルム、紙などにこのち法を 㟟用し，透湿カップ法とのデータ間の比較をしている。

しかし，布のように透湿が非常に大きい場合には，布 を通して水蒸気の移動が起り，高湿度䚋の湿度が一定に なりにくく，布も释時変化を受けるので，布の初期状態 での剆定には適しないであるう。そこで，水面上に常時 存在している水蒸気の桩散層を利用すれば，高湿度側の 調湿にこだわることなく，すぐに透湿性の測定が可能で ある。布の着用快適性の評価には，布の初期現象が必要 であり，上法を採用することにより，初期現象の測定が 可能となる。ここでは，管径 $8.2 \mathrm{~cm}$ の密閉容器を用いた 場合に拡散層の厚さがどの位になるかを，上田 ${ }^{b} の$ 万法 により求め，また害際に布をセっトした場合の影響の有 無につけて挨討した。
それらの得られた結果を基にして，ラミ一，ポリェス テルの混紡率を種々に変えた平織布を試料として実際に 透湿実験を行ない，ダイナミック法による透湿測定条件 を確立するとともに：一般的な定常的測定法に対する特 峌を論議した。

\section{2. 実 跧方法}

\section{1 試料}

表 1 に本実験に使用された布試料の明細を示す。布試 料は $20^{\circ} \mathrm{C} 65 \% \mathrm{RH}$ の温湿度条件中に1ケ月以上放㨟し たものを使用した。

厚さは thickness testerにより最低10回測定した。 通気度はフラジール型通気度試験機で測定した。

織維体積率Vf\%付 J I S L $1079(5,10,2)$ kもとつい て(1)式により算出した。

$$
V f(\%)=\rho^{\prime}, \rho \times 100
$$

ただし， ○’は布のみかけの比重，○は㵶維の比重を示す。

\section{2 容器内の水蒸気の惯度勾配}

ダイナミック法による透湿測定の容器は, 図1k示し てある市眅のセパラブルフラスゴを用いた。電谷湿度 計はエース製鋭感湿度計 $\mathrm{AH}-2 \mathrm{P}$ 型 $(20.0 \times 12.5 \times 0.5$ $\mathrm{mm}$ )を用いた。これに自記記録計をセットして，最大 20 分まで測定を稑けた。高湿度側は純水を用いたため $100 \%$ RH，低温度側屾测定室の温湿度を用いたため 20 $\pm 1{ }^{\circ} \mathrm{C}, 65 \pm 2 \% \mathrm{RH}$ ，水温は室温と同じく $20 \pm 1{ }^{\circ} \mathrm{C}$ とし た。電気温度計は水面近くから移動させ，移動量はカ七 トメーターで読みとった。

\section{3 布地の透湿性}

電気湿度計の位置は， 2.2 の检討の結果加ら，水面よ り $10 \mathrm{~mm}$ 以内(ここでは $10 \mathrm{~mm}$ に戦守)とし，布武料は その $0.5 \mathrm{~mm}$ 以下においた。布陚料は水の入ったカップ 部分に，周囲をビニールテープでとめ，側面からの水蒸 気の漏れを防止した。測定の 1 回目は試料を取り付けた 後直ちに，2回目以㦀はセンサーの付いた低湿度㑡部分 を取り外し，65\%雾围気中に，センサーと布陚料の片

Table 1 Characteristics of plain weave fabrics

\begin{tabular}{|c|c|c|c|c|c|c|c|c|c|c|}
\hline No. & $\begin{array}{c}\text { Blending } \\
\text { Polyester } \\
(x)\end{array}$ & $\begin{array}{c}\text { ratio } \\
\text { Ramie } \\
(\%)\end{array}$ & $\begin{array}{l}\text { Fabric } \\
\text { ends } / \text { in }\end{array}$ & $\begin{array}{l}\text { density } \\
\text { picks } / \text { in }\end{array}$ & $\begin{array}{r}\text { Cot } \\
\text { (Cotton } \\
\text { warp }\end{array}$ & $\begin{array}{l}\text { syst } \\
\text { syst } \\
\text { weft }\end{array}$ & $\begin{array}{c}\text { We ight } \\
\left(\times 10^{-2} \mathrm{~g} / \mathrm{cm}^{2}\right)\end{array}$ & $\begin{array}{l}\text { Thickness } \\
\left(\times 10^{-2} \mathrm{~cm}\right)\end{array}$ & $\begin{array}{c}\text { Volume } \\
\text { fraction } \\
\text { of fiber } \\
(\%)\end{array}$ & $\begin{array}{l}\text { Air permeability } \\
\left(\mathrm{cc} / \mathrm{cm}^{2} / \mathrm{sec}\right)\end{array}$ \\
\hline 1 & 0 & 100 & 79.6 & 68.6 & $29.2 \mathrm{~s}$ & $30.0 \mathrm{~s}$ & 1.259 & 2.03 & 41.3 & 77.5 \\
\hline 2 & 50 & 50 & 84.6 & 76.8 & 33.2 & 31.8 & 1.269 & 2.35 & 37.5 & 109.0 \\
\hline 3 & 55 & 45 & 84.2 & 77.3 & 33.1 & 32.6 & 1.245 & 2.31 & 37.6 & 98.4 \\
\hline 4 & 60 & 40 & 84.8 & 76.7 & 35.4 & 32.4 & 1.172 & 2.34 & 35.1 & 128.5 \\
\hline 5 & 65 & 35 & 83.9 & 77.4 & 32.3 & 33.3 & 1.235 & 2.33 & 37.3 & 114.1 \\
\hline 6 & 70 & 30 & 84.0 & 78.1 & 32.8 & 31.7 & 1.251 & 2.35 & 37.6 & 115.0 \\
\hline 7 & 75 & 25 & 84.0 & 77.9 & 320 & 30.5 & 1.238 & 2.35 & 37.4 & 118.0 \\
\hline 8 & 100 & 0 & 79.2 & 69.2 & 40.3 & 40.6 & 0.921 & 2.16 & 30.9 & 167.0 \\
\hline
\end{tabular}




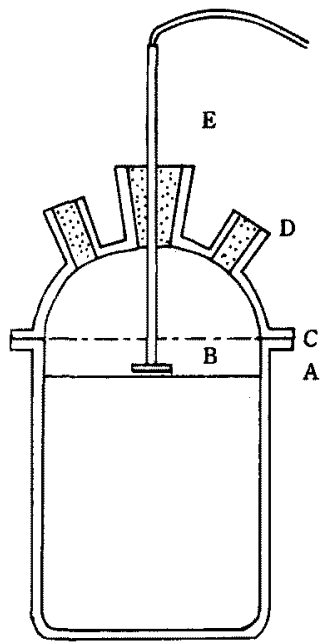

Fig. 1 Apparatus for moisture-permeability measurement.

A : Water surface

B : Receptor of electric hygrometer

C : Fabric sample

D : Stopper

E : Electric hygrometer

面を5分間暴露してから行なった。

\section{3. 結果と考察}

\section{1 容器内の水蒸気の漂度勾配}

まず湿度計の位置を変化させて容器内の湿度分布を調 べた。湿度勾配をわかり易くするために各測定位置に対 して湿度を測定時間別にブロットしたのが图 2 てある。 水面近くには拡散層を示寸涱度勾配がほぼ10 $\mathrm{mm}$ 付近ま で観察でき，それ以上ては対流層と思われるほぼ均一な 䁌が存在している。図3は水面をずっと低くした場合の 結果てあるが，対流域が直線状て，しかも应散增におけ るよりもずっとゆるやかな勾配が存在している。

測定を開始する以前には，水蒸気は大気中に定常的に 拡散している。その蒸気の浱度勾配をとらえるに際して 電気湿度計の応答は早いけれども，わずかに連れがある。 湿度変化の小さい場合は，遅扎は問題にならないが，変 化の大きい場合はこれを考虑に入れる必要がある。水面 近くに存在している执散屡は，高湿度側では常に $100 \%$ RHを起点としていなければならないのに水面付近ての プロットはやや遅れがちとなる。そこで, 実際の水蒸気 の漕度勾配から，上田の方法により水のみかけの拡散 䋆数を計算すると， $t=6$ 分でほぼ $0.25 \mathrm{~cm}^{2} / \mathrm{sec}$ を示 寸ことから，湿度計の遮れが $t=6$ 分ではなくなってお

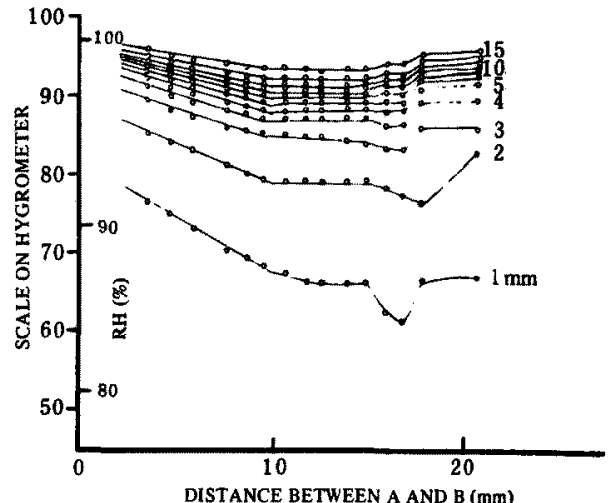

Fig. 2 Distribution of water vapour in the apparatus. (Distance between $A$ and $C$ is $12.5 \mathrm{~mm}$.)

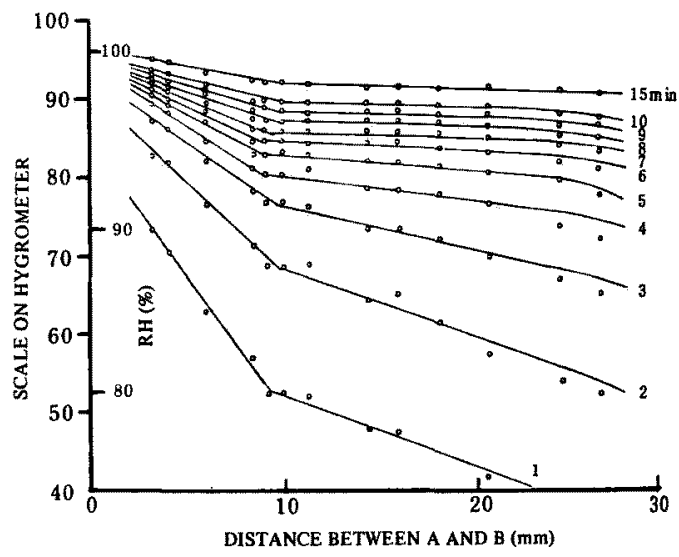

Fig. 3 Distribution of water vapour in the apparatus. (Distance between $A$ and $C$ is $27.0 \mathrm{~mm}$.)

り，布地の透湿性の䋓対的な議論ができていることを意 味している。故に，後で速べる布地の透湿性の解析には $t=6$ 分を用いている。

以上の結果から， $\phi=8.2 \mathrm{~cm}$ 容器の場合，水蒸気の应 散層の厚さは，水面から約 $10 \mathrm{~mm}$ まてとみなすことがて きる。しかし布地は透湿の大きなものであるから，抎散 層の有効厚ざ)よりわずかに上に布地を箸いた場合厸散 層の厚さに変化が起こることが考えられる。それ故，湿 度計から水面までの距離を变化させて，布地を監いた系 で透湿実験を行ない，蔽室側の湿度变化を時閏でブロ, トしたのが図 4 であり，更に水面からの距雠で湿度変化 をブロットしたのが図 5 てある。布地を膡かながった系 に較べ，效流域での勾配がやや大きくはなっているが， 拡散曆のそれとは，多少異なっている。また，その変曲 点は 10〜14 mmの間に観察される。それ故，本面から 


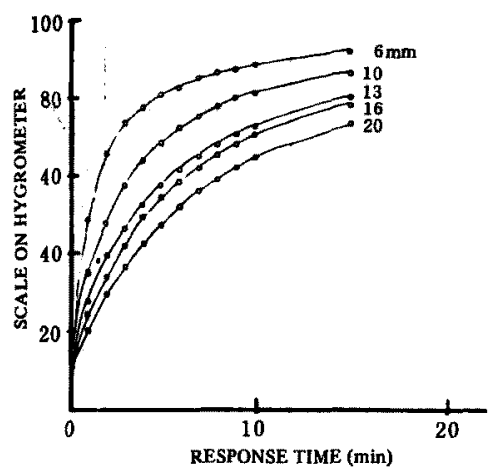

Fig. 4 Effect of fabric in the apparatus on diffusion rate of water vapour ( $100 \%$ ramie fabric).

Numbers in the figure show the distance between $A$ and $C$.

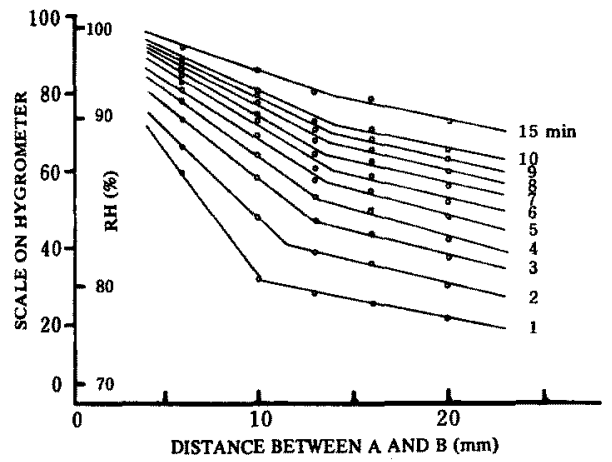

Fig. 5 Effect of varying distances between $A$ and $B$ on fabric moisture-permeation (See Fig. 4).

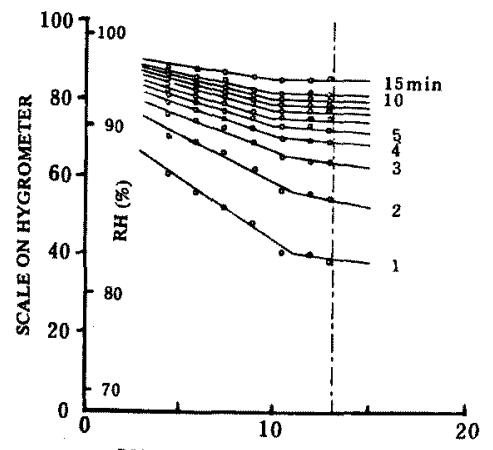

DISTANCE BETWEEN A AND B (mm)

Fig. 6 Distribution of water vapour below fabric sample which was placed at a distance of $13 \mathrm{~mm}$ above water surface.
$13 \mathrm{~mm}$ の位置に布地をはり，水面加ら布むでの水蒸気の 酸度勾をとらえた。この結果图6に示す。それによる と，水蒸気の拡散層は布が存在した場合でもや法り10 $\mathrm{mm}$ 以内と不変であり，10 $\mathrm{mm}$ 以上から布まての間に は，わずかではあるが対流層が存在しているのが認めら れる。

\section{2 布地の透湿性}

前項の捈討の結果から，水面から $10 \mathrm{~mm}$ まで位圈に 湿度計を賸き，その間に布地をセットすれば，透湿測定 が迅速，簡便にできるものと期待され，この点について 検討を加えた。試料No. 1 8 8での同一陚料について， 3 回透湿実験を繰り返した結果を時間に対しての礼室側 の湿度変化としてブロットしたのが図7に示してある。 いすれの試料も測定回数 $2 ， 3$ 回目のものは比較的再現 性が高い。2回目以降のデータに再現性が諗められるの はマイラーフィルムを用いた肴藤ら゙の結果と同様であ る。No-1で2，3回目のものが一致しないのは, 布試 料が2つの湿度勾配に依存した水分平衡に至っていない ことを意味する。

また，布地の透湿実験の 1 回目と 2 回目以降の測定值 を同一ダラフ上に比較した結果を图8に示した。いずれ の場合でもボリエステル混紡率の高なるほど透湿は早く

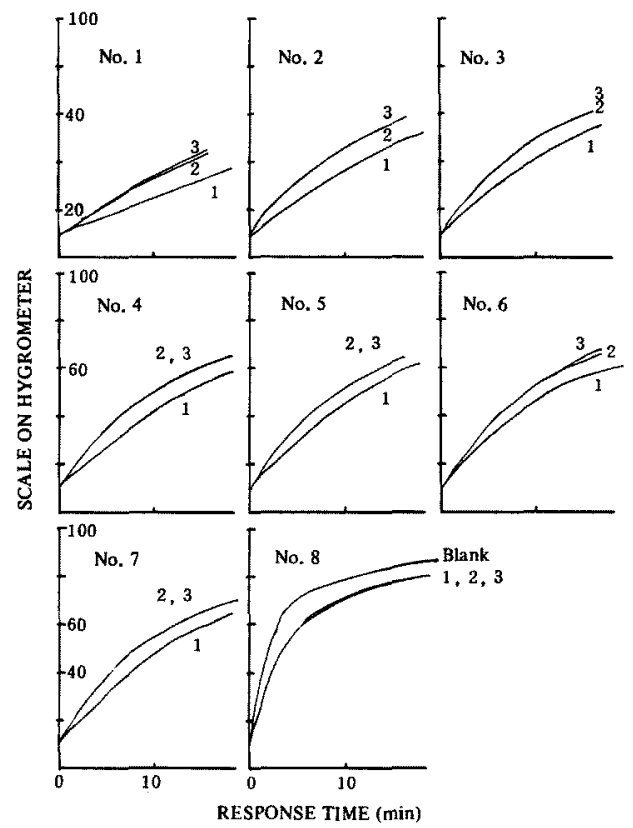

Fig. 7 Moisture-permeation curves of various blend fabrics. Numbers in the figure show the first, second and third measurements. 


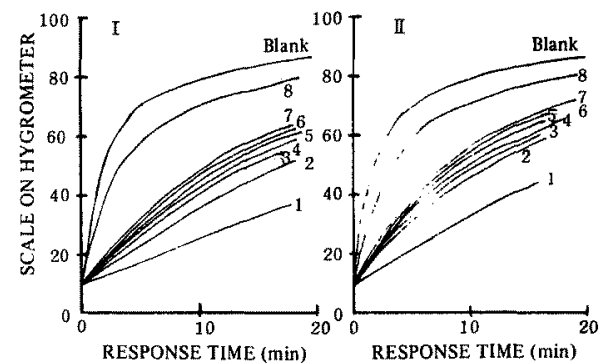

Fig. 8 Effect of blending ratio on moisture-permeability (See Fig. 7).

I : The first measurement

II : The second measurement

なっている。

また, 1 回目と 2 回目以降の測定で $t=6$ 分での透湿 性を布地を置かなかった㙫合からの透湿の漣れとし，相 対湿度に対してポリェステル混紡率をブロットしたのが 因 9 てある。1回目は 2 回目に比較してより初期現象と 言えるので，透湿の遅れが大きくなるのは当然である。 1 回目，2回目とも透湿の初期過程は瀻維素材と，すな わち吸湿性と密接な関係があることがわかる。

ここで，ダイナミック法による布地の測定をモデル的 に扱ってみると図10の示すような透湿過程が考えられ る。1回目の測定でAの過程を, 2 回目以降の測定て はBの迵程を考えることができるだろう。

また， 1 回目と 2 回目以降のデータからは，次の因子 が推察される。布体横をvとすると，

$\mathrm{A}$ の過程で布に吸湿される水分量 $\left(w_{A}\right)$ は $w_{A}^{*}=v *\left(\mathrm{C}_{1}-\mathrm{C}_{2}\right)$

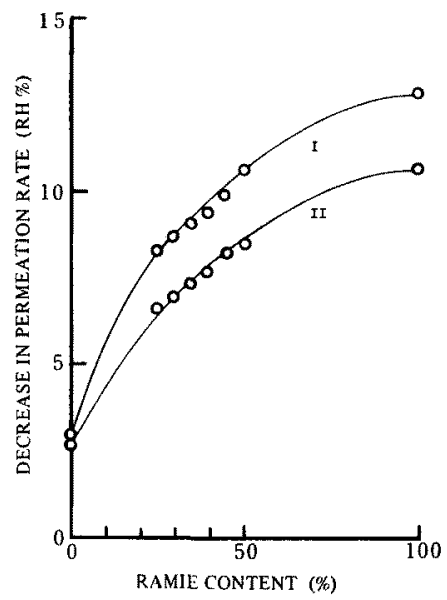

Fig. 9 Effect of ramie content on decrease in permeation rate (See Figs. 7 and 8 ).

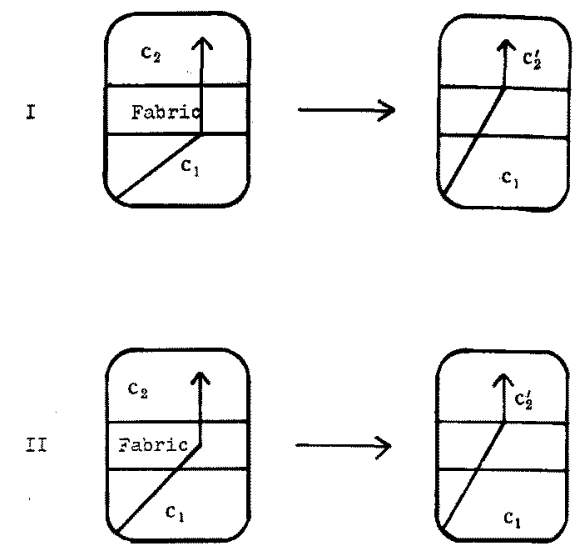

Fig. 10 Schemes of moisture distribution in the repeated measurements.

$\mathrm{C}_{1}, \mathrm{C}_{2}$ and $\mathrm{C}_{2}$ ' represent densities of water vapour in individual compartments.

Bの過程で布に吸湿される水分量 $\left(w_{B}\right)$ は

$$
w_{B}=v / 2 *\left(\mathrm{C}_{1}-\mathrm{C}_{2}\right)
$$

ここで， $\mathrm{C}_{1} ， \mathrm{C}_{2}$ は备部屋における水蒸気浱度 $\left(\mathrm{g} / \mathrm{cm}^{3}\right)$ とする。する，各測定回数間の差加らは

$$
w_{A}-w_{B}=v / 2 *\left(\mathrm{C}_{3}-\mathrm{C}_{2}\right)
$$

寸なわち，水分の吸収は有体皘の半量に対して起こるこ とが理解される。

1 回目と 2 回目以降のデータ間の差,すなわち，吸湿 性を科量法によって求めた結果を図11に示す。うミ一 泥綃率の高くなるはど、データ間の差が大きくなってい るのがわかる。つまり，この方法からは，布の絶対的な 吸湿量ではなく，単位面積当りの厚さ，織り方など，布

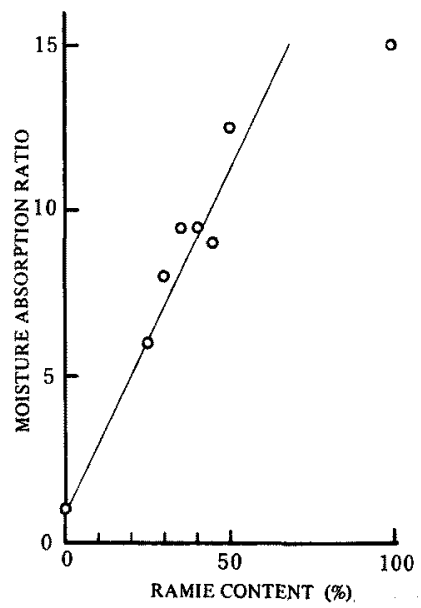

Fig. 11 Relationship between ramie content and moisture absorption (See Fig. 9). 
の着用快䔔性に缯く結びついた系での吸湿性が評価でき ると考えられこれんついては绥報で述べる。

また，水蒸気の移動は，布の固体部分からだけでなく 轿維空償を通しても起こっているので，ダイナミック法 は広義の透湿現象をむ測定しうるはずである。Whelan ${ }^{1 \mathrm{a}}$ らの解析に従がって，㵶維体皘率と厚さに対し，透湿の 遲れをプロットして，この点について検討を加えた。図 12に示した結果から明らかなように，織維体皘率につ いては直線夙係が認められる。厚さに関しては，試料間 の差異が比较的小さいために，明瞭な直線夙係が認めら れなかった。

また，通気度との関系をブロットしたのが图13であ る。通気度の小さいものほどブランクからの荤れが大き くなって拈り，この関係についても，值線関係が明らか に認められる。

したがって，本研究で確立された布地の初期現象を測

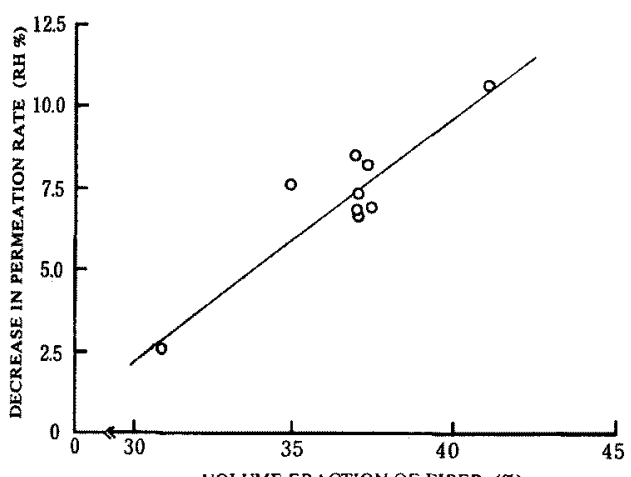

VOLUME FRACTION OF FIBER (\%)

Fig. 12 Relationship between volume fraction of fiber and decrease in permeation rate of water vapour.

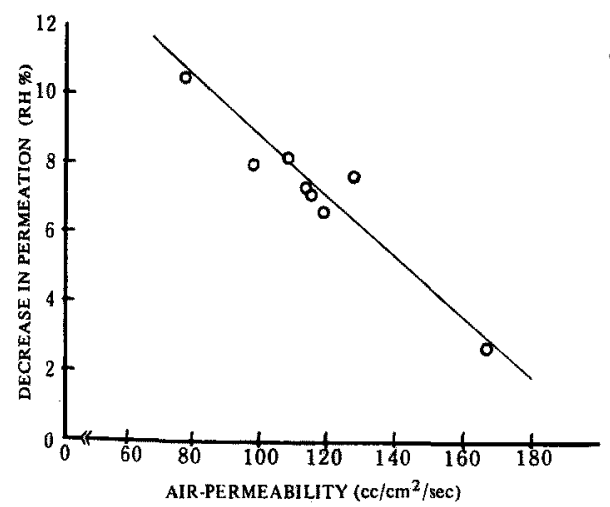

Fig. 13 Relationship between air-permeability and decrease in permeation rate of water vapour.
定するダイナミック法は，吸洎性に加えて，店我の透湿 現象をも同時に测定できることが明らかである。

\section{4. 総括}

布地の着用快適性に関逼寸るいくつかの物理的因子を 簡便，迅速に同時測定寸ることを目的として，密閉系の 非定常状悲に扔ける透湿測定として，電気湿度計を用い たダイナミック法の測定条件を検討し，また，布地に適 用した場合の本法の特長を，唀湿力ップ法など既存の力 法に対して墖議した。

(1) 管径 $8.2 \mathrm{~mm} の$ 円簡容器内に拟て, 水蒸氮の㹡

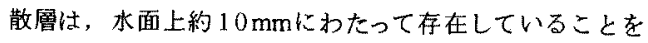
認奴。従って，この桩散層の範国内に電気湿度計を設 定することが，透湿の迅速測定の必要不可欠な条件とな る。

（2）この容器に，実際に布地を扗散層に接した外面に せットして，水面から布までの水蒸気の濃度勾配を求め た結果, 拡散層の厚さの変化は起らす，上の条件で，実 際の透湿測定が满足に行ならことができる。

（3）混紡率を8段階に変えたポリエステル/ラミ一布 について，実際に䧺湿実呀を行なった結果，予期したよ

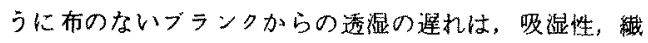
維体䅡率，通気度と直線関䋆をもつことかかかった。

以上の結果から，(1)の条件を満たした上での，ダィ ナシック法による布地の迹湿測定によって，広義の透湿 晛象に加え，看心地に関連するいくつかの重要な物理的 因子を同時に湘定できることが明らかとなった。

付記：本研究をまとめるに当り，貴重なご意見を賜わ

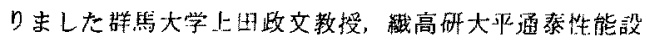

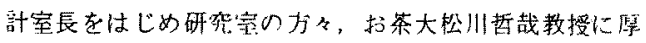
く御礼申し上げます。また，本畘究の遂行に当り，ご尽

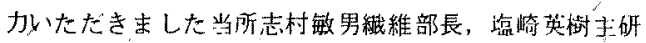
に心よりの感謝を电し」げます。

本研究の概要は，日本家政学会籍26回総合(1974年 10月3日東京)で発表した。

\section{文献}

1a) M.E. Whelan, L.E. Machattie, A.C. Goodings. L.H. Turl; Text. Res.J., 25, $197(1955)$

1b) L. Fourt, M. Harris ; Text. Res.J., 17, 256 (1947)

1c) 安井康二，亀井博子，瀻消誌，3，3(1962)

1d）丹羽雅子, 高田範子, 户㧘伸子; 栦消誌, 6, 185 (1965)

2) 高分子学会編；材料と水分ハンドブック（共立出 版 ) $201(1968)$

日本化学会編；実験化学請座，8，(下巻)，(九 善) $165(1957)$ 
3）丹羽雅子；瀻消誌，9，56(1968）その他,

4) 竟藤幸男，芹沢竜之介，松下和昭；材料試験，5，

上田政文，芝 龟吉；応用物理，33，269(1964) 423(1956)

5）上田政文；応用物理，25，144(1956)

上田政文；計量管理，7，29(1958)

鉿木 渟，大平通泰；絨学誌，26，107(1970)

6）西村緵子，松川暂；お茶大卒業論文 (1969)

\title{
$\mathrm{N}, \mathrm{N}^{\prime}$ ジメチロール樹脂加工剤の重縮合物
}

\author{
東京工業大学工学部有機材料工学科 顔 明 雄 - 砺波 宏明
}

\section{POLYCONDENSATION PRODUCTS OF N, N'-DIMETHYLOL RESIN FINISHING AGENTS}

\author{
By Meng Shung Yen and Hiroaki Tonami
}

(Department of Textile and Polymeric Materials, Faculty of Engineering, Tokyo Institute of Technology, Ookayama, Meguro-Ku, Tokyo)

Chemical constitutions, i.e. $\mathrm{N}-\mathrm{CH}_{2} \mathrm{OH}, \mathrm{N}-\mathrm{CH}_{2} \mathrm{OCH}_{2}-\mathrm{N}$, and $\mathrm{N}-\mathrm{CH}_{2}-\mathrm{N}$, of the polycondensation products of dimethylol ethylene urea (DMEU) and dimethylol propylene urea (DMPU) prepared under the various curing conditions were studied. $\mathrm{N}-\mathrm{CH}_{2} \mathrm{OH}$ and free $\mathrm{CH}_{2} \mathrm{O}$ in the reaction products were determined separately by the application of the $\mathrm{KCN}$ method. Contents of $\mathrm{N}-\mathrm{CH}_{2} \mathrm{OCH}_{2}-\mathrm{N}$ and $\mathrm{N}-\mathrm{CH}_{2}-\mathrm{N}$ were determined separately from the difference of their hydrolysis rates to acetic acid, and confirmed by the NMR method. The kinetics in these hydrolyses were also studied.

Chemical constitutions of the polycondensation products were affected remarkably by their curing time and temperature. With changing the curing time at $120^{\circ} \mathrm{C}, \mathrm{N}-\mathrm{CH}_{2} \mathrm{OCH}_{2}-\mathrm{N}$ was formed rapidly at first, and then decreased with time, while contents of $\mathrm{N}-\mathrm{CH}_{2}-\mathrm{N}$ and free $\mathrm{CH}_{2} \mathrm{O}$ increased at about the same rate with time. It was suggested that the $\mathrm{N}-\mathrm{CH}_{2} \mathrm{OH}$ in DMPU or DMEU was rapidly consumed for the formation of $\mathrm{N}-\mathrm{CH}_{2} \mathrm{OCH}_{2}-\mathrm{N}$, which decomposed gradually into $\mathrm{N}-\mathrm{CH}_{2}-\mathrm{N}$ and free $\mathrm{CH}_{2} \mathrm{O}$ in the polycondensation. The similar tendencies for the formation of $\mathrm{N}-\mathrm{CH}_{2} \mathrm{OCH}_{2}-\mathrm{N}, \mathrm{N}-\mathrm{CH}_{2}-\mathrm{N}$ and free $\mathrm{CH}_{2} \mathrm{O}$ were also found with changing the curing temperature for $30 \mathrm{~min}$. Degrees of polycondensation of DMPU and DMEU oligomers, in both cases, reached $9-10$ in maximum. It was also found that $\mathrm{Zn}\left(\mathrm{NO}_{3}\right)_{2}$ showed excellent catalytic action leading to the formation of $\mathrm{N}-\mathrm{CH}_{2}-\mathrm{N}$ in considerable amounts, but $\mathrm{MgCl}_{2}$ only affected the formation of $\mathrm{N}-\mathrm{CH}_{2} \mathrm{OCH}_{2}-\mathrm{N}$, and $\mathrm{Mg}\left(\mathrm{CH}_{3} \mathrm{COO}\right)_{2}$ had almost no catalytic action under a curing condition, $120^{\circ} \mathrm{C}, 30 \mathrm{~min}$.

(Received January 17, 1975)

\section{1. 緒 \\ 言}

セルロース織物の楅脂加工は，樹脂加工澈として一般 に尿素または尿素誘導体の $\mathrm{N}, \mathrm{N}^{\prime}$ ーシメチロール化合物が 用いられ，ハッドーキュア万式によって加工され，セル

*この報文を「セルロース織物の樹脂加工に関する研究 (第1報), Studies on the Finishing of Cellulose Fabrics (Part 1)」とする。
ロ一ス分子間の橋かけの生成によって防しか勃果が得ら れている。このとき起る反応は，ィチロール基とセルロ

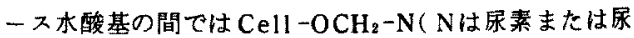
素誘導体残基のN) を, なチロール基同士の間ではメチ レンエーテル結合 $\left(\mathrm{N}-\mathrm{CH}_{2} \mathrm{OCH}_{2}-\mathrm{N}\right)$ とィチレン結合 $\left(\mathrm{N}-\mathrm{CH}_{2}-\mathrm{N}\right)$ を 2 段陵に生成し ，その結果尿素残基 1 ないし数個からなる㰌がけが生成されるものとされてい $ろ^{2,8)}$ 。 